\title{
Editors' Note: Presence of Randy Martin
}

Dance studies as an academic discipline in the Western world is now sufficiently established to have its own lore. Knowing about the destabilizing importance and political function of gossip and storytelling (Besnier 2009), we want to start this special issue celebrating Randy Martin's formative impact on the field with one such tale. The dancer, scholar, and social activist Randy Martin who established himself as an influential voice in our field in 1998 with the seminal publication Critical Moves: Dance Studies in Theory and Politics was never hired by a dance department. Yet, as the story goes, he did interview with one of the main Dance Studies departments in the early years and was asked during the interview if, as a dancer and sociologist, he could commit to his future work being situated in the parameters of the field of dance studies. Apparently Randy replied that he could not. At that time he was professor in the department of Social Science and Cultural Studies at the Pratt Institute, was subsequently appointed associate dean of the Tisch School of the Arts, NYU, and, in 2000, became chair of the Department of Art and Public Policy; in 2006 he founded the MA in Arts Politics. Interestingly enough, he never really left the field of dance and informed it with all his future publications, his administration, and his pedagogy.

We bring this story back to life here because it allows us to understand Randy Martin's unique contribution to dance studies and at the same time forces us to think about the parameters of the discipline. How does Randy's work inform our discourse? And what has our discipline become in relation to other fields of inquiry and as a political force?

It is also worth noting in this connection that at the start of his career Randy was a professional dancer before turning full-time to intellectual engagement. Randy began taking dance classes at UC Berkeley in the late 1970s concentrating on Graham technique with David Wood and Marnie Thomas Wood. During his Master's work at the University of Wisconsin he met Claudia Gitleman who, at a summer workshop, encouraged him to come to New York City and study with Alvin Nikolais and Murray Louis. Between 1983 and 1988 Randy danced with Claudia Gitelman, Martha Bowers, Pooh Kaye, and Nina Martin. ${ }^{1}$ Throughout the 1980s he was presenting his work as both a choreographer and a theater director. ${ }^{2} \mathrm{He}$ also practiced clowning. Hence, it was the case that Randy's thinking and writing on dance were embedded in his dance and theater practices.

As a dancer, Randy had to have been affected by the economics of production during the 1980s when, under Reagan, the strategy of nonprofits was beginning to saturate the field alongside the ultimately untenable entrepreneurial idea that dance was a business. ${ }^{3}$ In his last book, Knowledge LTD. Toward a Social Logic of the Derivative (2015), Randy gave detailed attention to the conundrum of philanthropy in the United States and the dilemma of the artist's survival. His experience as a dancer surely influenced his idea for the creation of an MA in Arts Politics at NYU. His analysis of arts funding in Knowledge LTD., such as it is in the United States, was far from enthusiastic. He did not express his advocacy for dance blindly. The question of how Randy's work informs our discourse today in dance studies is thus one that demands reflection across his entire corpus. (For this reason, we include a checklist of his major publications in this special issue). And, finally, the 
disciplinary question we raise also relates to Randy's own intellectual formation in the academy. Sociology was the discipline within which his thought was initially schooled, yet a reflection on ethnography and an interest in theater was also present at an early stage of his writing. No matter what discipline we evoke-either academically or performatively-Randy's relation to it was purposively precarious and in this way can be said to have performatively foreshadowed his interest in precarity and volatility later in his career.

Yet, Randy not only moved dance across disciplines, but early on he also broadened key concepts in our discipline. For instance, in the last chapter of Critical Moves Randy highlights the labor that choreography can achieve and initiate cross-culturally. Randy's definition of multicultural bodies as "composite, instanced by immediate and mediated associations and not amalgamations of fixed identities within stable group members" (212) is especially productive for a comprehension of dance's agency in a United States divided by race and class wars and maybe even more so globally in the shaping of societies facing a refugee crisis caused by contemporary warfare and climate change. Fully aware of the potentiality of the transformation of multiculturalism by state and economic forces into a commodification and the disciplining of difference as "a property of individual bodies," Randy suggests that "dance can contribute to the larger political discussion ... [because] both choreography and dancing remain practices that present their own amalgamation of structure and agency" (213). And "critical dance studies can develop an account of their interpenetration of structure and agency that makes palpable the radical contingency of these two analytic terms, without losing sight of the appropriation of surplus that necessitates a critique of domination" (216). Thus, dancing and also the theorization of dance and choreography move outside the Western academic context, a move reflected in the broadening of dance studies into minority, ethnic, and race studies and its establishment in universities in the Global South and Asia.

In all these cases, and probably more that we have not mentioned, Randy extracted acute insights that veritably, and somewhat miraculously, leapt across the seeming divide between dance and the sociopolitical sphere, capturing in visionary phrases, and sometimes against all odds, how dancing, choreography, and technique animate as if from within planes of reflection and action that otherwise would be bereft of theoretical foundation-and he accomplished this in the very sphere of practice itself. This is part of the meaning of being at one and the same time inside and outside dance "itself." What we evoke here are thus not metaphors but structural necessities of analysis, and the supreme irony is that such structural necessities would not be articulable without dancing. Dance enabled Randy to think about movement outside social systematicity and, to a certain degree, even outside aesthetics. In place of the aesthetic his work ultimately posited the kinestheme, a relative of Foucault's episteme. That is, dance itself, in Randy's terms, is the working theory of practice where movement and the social intertwine or interweave, a practice that exists in a sphere of analysis that is shown to have been lacking its own terms all along. As Mark wrote in the Social Text's special tribute, "Movement after Randy Martin," curated by May Joseph (2015), "Randy has an infallible eye for the transmutability of movement into social movement. His take on the energy of movement opens upon a rich web of associations, which are those of dance itself" (Franko 2015, 129). And as Barbara Browning wrote in the same issue, "Randy's invocation of the term 'mobilization' in relationship to dance practice wasn't simply a play on words-it wasn't enough to think of dance's metaphoric relationship to political movements. We need to really examine the political dimensions of movement practices and the choreographic aspects of our political engagements" (Browning 2015, 138). Both of these comments seem to underline our point about the invisible dividing line between dance and social movement that Randy pinpointed not as metaphor but as pragmatic-theoretic reality. As hard as it is to axiomatize exactly what he accomplished with this amazing sleight of hand, we must admit that the very difficulty of its articulation points to the originality and justesse of the insights Randy put down on the page.

If we return with this assessment to our initial question about the influence of his work on broadening the discourse in our field, it is productive to look at Randy's last theoretical contribution to 


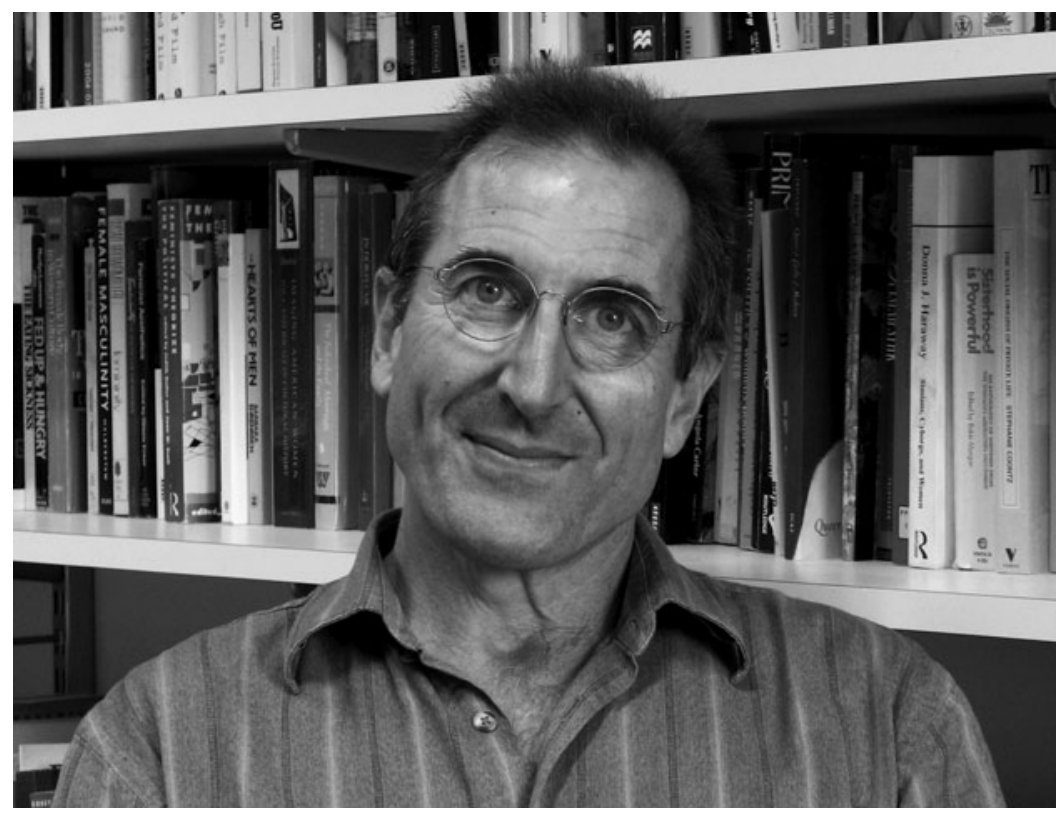

Photo 1. Randy Martin. Courtesy of Ginger Gillespie.

concepts that have been central to dance studies and that advance the field toward political commitment. At the international symposium "Dance, Politics, and Co-Immunity" in 2010 at the University of Gießen in Germany, Randy provided a glimpse into his interdisciplinary thought system that would be most prominently developed in Knowledge LTD. (2015). In this talk "Mobilizing Dance: Toward a Social Logic of the Derivative," Randy expanded on concepts of movement, mobility, and collectivity, but also on institutionalization, ephemerality, and utopia (Martin 2013b).

Spurred on by the financial crisis of 2008 and, more important, by his ongoing corpo-realized rethinking of global financial systems, Randy reorganized the concept of the derivative, which as a financial instrument provides a risk insurance or hedging against future financial speculations or market shifts by bundling disparate financial entities, such as interest rates, assets, or currencies, and which can be traded independently of the actual value of its bundled entities. Randy saw a similar bundling of seemingly disparate entities in other areas outside the economy, for instance, in the way so-called identity is a bundling of personal, cultural, and political entities; aspects of that identity can then be valued and circulated beyond the actual individual $(2015,211)$. Explained by a brief discourse into classical, modernist, postmodern, or contemporary dance history, Randy then theorized some dance-such as postmodern dance, hip hop, and movement originating in boarding culture-as also practicing derivative logic in their decentered, post-colonial social kinesthetic and lateral mobility:

The underlying sources of pedestrian, slave, and indigenous bodily practices are decolonized from their initial terms and settings to refigure those who by tradition would be assigned to the populations at risk into crafting corporal economies where risk counts as its own reward. A risky move is granted immediate value by the creative ensemble, it need not await final delivery precisely in the manner that a derivative affords a price on a good or service that has not yet been made or come due. (222)

Reappropriating the damaging financial instrument of the derivative as a constructive force-a "generative derivativeness" (Martin 2012, 72) —in dance allowed Randy to powerfully demystify the "trap of ephemerality and location" that has haunted the study of dance for centuries (224). "Performances are, after all, derived from many other times, of rehearsal, of training, of touring; 
and they gather together movements from myriad locales, experiences, sources and recalibrate and recompose them for a given intervention. Seen from this expanded field, dance is already everywhere" (224). This omnipresence of dance speaks to a certain understanding of mobilization as a concept that returned to reassert social energies lurking within the derivative.

And in Randy's understanding, dance could even touch utopia because dance can creatively mobilize and bundle elements out of these vastly different experiences, localities, and times-even if they had a negative impact on our bodies. "Valuing the ways in which we are linked together without being one, that we share certain sensibilities of moving together without needing to model or imitate some one opens conceptions of sovereignty as self-production that just might serve as a momentary realization of the future in the present" (225). Randy's persistent and determined investigation of the codependent relationship between the choreographic and the social thus provided a constantly evolving and affirmative model for social mobilization. What Randy opposed in sociology was systems thinking, which is why dance afforded him a relational frame within which to conceive of the interaction between dancer and spectator as a model for the theory of social movement(s). ${ }^{4}$

One of Randy's last projects was editing the Handbook of Dance and Politics (2017) for Oxford University Press with Gerald Siegmund and Rebekah Kowal, and when this volume appears, we will certainly gain more insight into his thinking. But he also contributed a chapter to the Handbook of Dance and Reenactment (forthcoming from Oxford University Press in 2017). This provides another example of how Randy adapted dance materials that would later appear in Knowledge LTD to the problematic of reenactment in dance. In his chapter, "Scenes of Reenactment/Logics of Derivation in Dance," Randy addresses reenactment at a certain remove from historical reenactment in dance performance to envision it as a repurposing of movement common to several strands of dance in postmodernity. What is different from our earlier example is that here Randy makes use of a trend in contemporary dance-the reperformance of the work of a predecessor-in order to ground the theory of the derivative in/as movement in movement itself. If there were still doubts, the metaphorical role of dance is here entirely washed away. For Randy, danced reenactment is just one example of the derivative logic in dance more generally, and for this reason reenactment should be viewed from this widened perspective. In this context, historicization has nothing to do with the past and everything to do with the present and the future or, more precisely, with the present at risk to and in the future. "The triptych of classical, modern and postmodern ways of knowing would more properly be rendered as a trivium, as three ways of moving that come together" (Martin 2012, 71). This trivium refers to "the divine verticality that orients balletic movement" (ibid.), which can be linked historically to political sovereignty, to modernism's "extraordinary dimension of depth" where Graham is the iconic example, and, finally, to the decentered social kinaesthetic associated with Trisha Brown, break dancing and boarding culture, the latter demonstrating an extreme reorientation to space as a flow through horizontality. In dance, as with financial investment, the "market" is therefore in futures. But in reenactment, fragments of the past bundled together may also have futures. Moreover, the derivative harbors a social logic, one in which what unites disparate forms of dance is the kinestheme. The "postmodern" forms "in which decolonized bodies assert other modalities of risk," Randy specifies, "are themselves derivative forms that share not so much aesthetic influence as attributes that are features of their self-production" (Martin 2012, 73). This self-production takes place against formidable odds in hostile social space and therefore deploys techniques that must not infrequently be contrived on the spot: they are in and of themselves volatile responses to precarity.

It is the particular privilege of dance to make a way of moving that seems to have originated in finance as volatility - a kind of compulsory movement that does not know itself-become legible as a social logic. The way that volatility as the ephemeral par excellence can become an object of knowledge-get beyond the limitations it seems to posit for knowledge-depends on how it can be captured in a "tangible corporeal animation" (Martin 2012, 70). The reason finance is inscrutable is that "it generates no language of movement" (ibid.). But this is precisely what dance 
does do, and it is what dancers do know: dance is not only the site of mobilization; it grasps mobilization as a language. "Mobilization pertains to the medium-generating consequences of movement that render tangible the otherwise ephemeral entailments of time and space" (ibid.).

The legibility of the derivative that dance promises-and its own legibility as itself historically derivative-is possible only because dance does know itself, operates in full cognizance of its own history in which its technical and choreographic principles are embedded. Dance thus is able to reenact those bits and pieces of its past in ways that create intentional difference as knowledge through corporeality. The reference to the medium here is the subtle but decisive giveaway that Randy is a dance scholar, that his treatment of dance is anything but metaphorical, and that dance as knowledge is politically mobilizing. The essays collected here further expound upon and develop these points, and we hope they also indicate that there is a great deal more to glean from reflection on Randy's body of work.

Mark Franko

Editor, Dance Research Journal

Jens Richard Giersdorf

Guest Editor, Dance Research Journal

\section{Notes}

1. In the early 1980s Randy also studied method acting and directing at the Ernie Martin studio (his interest in theater as well as dance is notable in Performance as Political Act and Socialist Ensembles). We would like to thank Ginger Gillespie for providing these specifics on Randy's performance career and for allowing us to publish most of the images in this issue. We wish to thank Kathy Engel for additional images.

2. Sometimes You Gotta Break it to See how to Fix It was produced with Ginny Wollaston at the Charas, Inc., Teatro La Terraza, in July 1983, and The Flattening of a President Charas Theater was produced in 1984.

3. See his discussion of boom and bust in Critical Moves (1998, 85-92).

4. "The conceit of the system metaphor is that the relation of parts to whole is known beforehand and that each retains its integrity, which fixes its position, interest and contribution" (Martin 2013a, 90).

\section{Works Cited}

Besnier, Niko. 2009. Gossip and the Everyday Production of Politics. Honolulu: University of Hawai'i Press.

Browning, Barbara. 2015. "Difficult Movement." Social Text 124 (September): 138-39.

Franko, Mark. 2015. "The Kinetics of Dance Theory and the Social Movement of Desire." Social Text 124 (September): 129-30.

Martin, Randy. 1998. Critical Moves: Dance Studies in Theory and Politics. Durham: Duke University Press.

— 2012. “A Precarious Dance, a Derivative Sociality.” TDR. The Drama Review 56 (4): 64-79. . 2013a. "After Economy? Social Logics of the Derivative." Social Text 114 (31/1): 83-106. . 2013b. "Mobilizing Dance: Toward a Social Logic of the Derivative." In Dance, Politics \&

Co-Immunity, edited by Gerald Siegmund and Stefan Hölscher, 209-25. Zurich: Diaphanes.

- 2015. Knowledge, LTD: Toward a Social Logic of the Derivative. Philadelphia: Temple University Press.

- 2017. "Scenes of Reenactment/Logics of Derivation in Dance." In Handbook of Dance and Reenactment, edited by Mark Franko. New York: Oxford University Press.

Siegmund, Gerald, and Stefan Hölscher, eds. 2013. Dance, Politics \& Co-Immunity. Zürich: Diaphanes. 


\section{A Bibliography of Major Published Works by Randy Martin}

[This is an attempt to compile an exhaustive list of monographs, edited collections, articles and book chapters published by Randy Martin. Shorter articles and book reviews have not been included. —The Editors]

\section{Single Authored Books}

2015. Knowledge, LTD: Toward a Social Logic of the Derivative. Philadelphia: Temple University Press.

2011. Under New Management: Universities, Administrative Labor and the Professional Turn. Philadelphia: Temple University Press.

2007. An Empire of Indifference: American War and the Financial Logic of Risk Management.

Durham, ND: Duke University Press, Social Text Books.

2002. Financialization of Daily Life. Philadelphia: Temple University Press.

2002. On Your Marx: Relinking Socialism and the Left. Minneapolis: University of Minnesota Press. 1998. Critical Moves: Dance Studies in Theory and Politics. Durham, NC: Duke University Press.

1994. Socialist Ensembles: Theater and State in Cuba and Nicaragua. Minneapolis: University of Minnesota Press.

1990. Performance as Political Act: The Embodied Self. New York: Bergin \& Garvey Publishers.

\section{Edited and Co-Edited Volumes}

2017. Handbook of Dance and Politics. Edited by Gerald Siegmund, Rebekah Kowal, and

Randy Martin. New York: Oxford University Press.

2016. Derivatives and the Wealth of Societies. Edited by Benjamin Lee and Randy Martin. Chicago:

University of Chicago Press.

2015. Routledge Companion to Art and Politics. Edited by Randy Martin. London: Routledge.

2007. The Returns of Alwin Nikolais: Boundaries, Bodies and the Dance Canon. Edited by

Claudia Gitelman and Randy Martin. Middletown, CT: Wesleyan University Press.

2006. Artistic Citizenship: A Public Voice for the Arts. Edited by Randy Martin and Mary Schmidt Campbell. London: Routledge.

1999. Chalk Lines: The Politics of Work in the Managed University. Edited by Randy Martin.

Durham, NC: Duke University Press.

1999. SportCult. Edited by Randy Martin and Toby Miller. Minneapolis: University of Minnesota Press. 1993. New Studies in the Politics and Culture of U.S. Communism. Edited by Michael E. Brown,

Frank Rosengarten, George Snedeker, and Randy Martin. New York: Monthly Review Press.

\section{Articles and Chapters}

2017. "Scenes of Reenactment/Logics of Derivation in Dance." In The Oxford Handbook of Dance and Reenactment. Edited by Mark Franko. New York: Oxford University Press.

Forthcoming. "Divisions and Hierarchies." In A Companion to Critical and Cultural Theory. Edited

by Imre Szeman et al. Oxford: Blackwell.

2015. "What Has Become of the Professional Managerial Class?" The Socialist Register.

2015. "Money After Decolonization." SAQ 114(2): 377-393.

2015. "Coming Up Short: Knowledge Limits and the (Un)Making of the Professional Managerial

Class." International Critical Thought 5(1): 95-110. [First published in 2014 in Polygraph 23/24]. 2014. "Of Dance, Derivatives, Decolonization and Kinesthemes." TkH 21: 73-78.

2014. "What Difference Do Derivatives Make? From the Technical to the Political Conjuncture." Culture Unbound 6(1): 189-210. 
2013. "Linked Fates and Futures: Communities and Campuses as Equitable Partners?" Public: Arts/ Design/Humanities A Journal of Imagining America 1(1-2). [doi: http://public.imaginingamerica. $\mathrm{org} / \mathrm{blog} /$ article/linked-fates-and-futures-communities-and-campuses-as-equitable-partners/] 2013. "Mobilizing Dance: Toward a Social Logic of the Derivative." Dance, Politics \& Co-Immunity.

Edited by Gerald Siegmund and Stefan Hölscher, 209-225. Zürich: Diaphanes.

2013. “After Economy: Social Logics of the Derivative." Social Text 114/31(1): 83-106.

2012. “A Derivative Dance, A Precarious Sociality.” The Drama Review (TDR) 56(4): 64-79.

2012. "An Important Failure: Knowledge Limits and the Financial Crisis." Co-authored by Dick

Bryan, Randy Martin, Johnna Montgomerie, and Karel Williams. Introduction to Special Feature of Economy and Society 4(3): 299-315.

2012. "Bailout." In Impasses of the Post-Global: Theory in the Era of Climate Change, Vol 2. Edited by Henry Sussman, 232-250. Ann Arbor, MI: Open Humanities Press.

2011. "Taking an Administrative Turn: Derivative Logics for a Recharged Humanities." Representations 116: 156-176.

2011. "From the Race War to the War on Terror." In Beyond Biopolitics: Essays on the Governance of Life and Death. Edited by Patricia Clough and Craig Willse, 258-275. Durham, NC: Duke University Press. 2011. "Between Intervention and Utopia: Dance Politics." [From 2009 Tanzkongress] In Emerging Bodies: The Performance of World Making in Dance and Choreography. Edited by Gabriele Klein and Sandra Noeth, 29-46. Bielefield: Transcript.

2011. "Durable Ephemeralities: Arts Agencies." In Expanding Scenography. Edited by Thea Brejzek, 78-83. Prague: Quadrennial.

2010. "The Good, The Bad, and the Ugly: Economies of Parable." Cultural Studies Volume 24(3-4): 418-430.

2010. "Politics of Association/Trajectories of Affiliation" Lateral: Journal of the Cultural Studies Association. June. (E Journal with no pages.)

2010. "Specters of Finance: Limits of Knowledge and the Politics of Crisis." Journal of Communication Inquiry 34: 355-365.

2010. "What's in It for Us? Rethinking the Financial Crisis." Rethinking Marxism 22(2): 187-194. 2010. "Toward a De-Centered Social Kinesthetic." Dance Research Journal 42(1): 77-80.

2009. "Whose Crisis Is That? Thinking Finance Otherwise." Ephemera: Theory and Politics in Organization 9(4): 344-349.

2009. "Collective." Co-authored with Brent Edwards and Anna McCarthy. Social Text 100: 74-77. 2009. "University." Co-authored with Eng-Bend Lim. Social Text 100: 251-256.

2009. "Academic Activism." PMLA 124(3): 838-846.

2009. "The Twin Towers of Financialization: Entanglements of Political and Cultural Economies."

Global South 3(1): 108-125.

2009. "Financialization and Marx: Giving Labor and Capital a Financial Makeover." Co-Authored with Dick Bryan and Mike Rafferty. Review of Radical Political Economy. 41(4): 458-472.

2008/2009. "W(h)ither Academic Freedom? Revaluing Faculty Work." Works and Days 26/27: 371-388. 2008. "Financialization, Risk and Labour." Co-authored with Dick Bryan and Mike Rafferty.

Competition and Change 12(2): 121-133.

2008. “Allegories of Passing in Bill T. Jones.” Dance Research Journal 40(2): 74-87.

2008. "Dance's Diversity: A U.S. Perspective" Dance: Transcending Borders. Edited by

Urmimala Sarkar. New Delhi, India: Tulika Books.

2007. "War, By All Means." Social Text 91: 13-22.

2007. "Mode of Excess: Bataille, Criminality and the War on Terror." Co-authored with

Stefano Harney. Theory and Event 10(2).

2007. "Art Attacks." Women and Performance 17(3): 283-298.

2007. "Editor's Preface." In Returns of Alwin Nikolais: Bodies, Boundaries and the Dance Canon.

Co-authored with Claudia Gitelman. Edited by Claudia Gitelman and Randy Martin, vii-x.

Middletown, CT: Wesleyan University Press.

2007. "Nikolais Returns." In Returns of Alvin Nikolais: Bodies, Boundaries and the Dance Canon. Edited

by Claudia Gitelman and Randy Martin, 1-25. Middletown, CT: Wesleyan University Press. 
2007. "Organizations as Social Structures." In Blackwell Encyclopedia of Sociology. Edited by George Ritzer, Volume VII, 3321-3325. Oxford: Blackwell Publishing.

2006. "Toward a Kinesthetics of Protest." Social Identities 12(6): 791-801.

2006. "CityCorps." [Editorial Introduction to special Issue of Space and Culture]. Edited by

May Joseph and Randy Martin, 232-234. Space and Culture 9(3).

2006. "Productive Pleasures: Episodes of a Critical Public in Cuban Dance." Space and Culture 9(3):

254-260.

2006. "Introduction." In Artistic Citizenship. Edited by Mary Schmidt Campbell and Randy Martin, 1-22. New York: Routledge.

2006. "Derivative Wars." [Special issue of Cultural Studies on Homeland Security]. Edited by

Mark Andrejevic and James Hay, 459-476. Cultural Studies 20(4-5).

2006. "Where did the future go?" Logos 5(1): http://www.logosjournal.com/issue_5.1/martin.htm. 2005. "Staging the Political: Boal and the Horizons of Theatrical Commitment." In The Joker Runs

Wild. Edited by Jan Cohen Cruz and Mady Shutzman, 23-32. New York: Routledge.

2004. "Introduction." [Special issue entitled "Turning Pro: Professional Qualifications and the

Global University"]. Edited by Stefano Harney and Randy Martin, 1-11. Social Text 79.

2004. "Introduction: Corruption in Corporate Culture." Co-authored with Ella Shohat. Edited by

Randy Martin and Ella Shohat, 1-7. Social Text 77.

2004. "America as Risk/Securitizing the Other." Interventions: International Journal of Postcolonial Studies 6(3): 351-361.

2004. "Foreword." In Tenured Bosses and Disposable Teachers: Writing Instruction in the Managed

University. Edited by Marc Bousquet, Tony Scott and Leo Parasondola, ix-xi. Carbondale, IL:

Southern Illinois University Press.

2004. "Dance and Its Others: Theory, State, Nation, and Socialism." In Of the Presence of the Body:

Essays on Dance and Performance Theory. Edited by Andre Lepecki, 47-63. Middletown, CT: Wesleyan University Press.

2002. "Geography Financialized." In Implicating Empire. Edited by Stanley Aronowitz and

Heather Gautney, 211-228. New York: Basic Books.

2002. "Introduction: 911: A Public Emergency?" Co-authored with Ella Shohat, 1-8. Social Text 72.

2002. "Rallying Social Text." Co-authored with Brent Edwards, 1-9. Social Text 70.

2001. "The Renewal of the Cultural in Sociology." In The Blackwell Companion to Cultural Studies.

Edited by Toby Miller, 63-78. Oxford: Blackwell Publishing.

2000. "Modern Dance and the American Century." In A Modern Mosaic: Art and Modernism in the

United States. Edited by Townsend Ludington, 203-226. Chapel Hill, NC: University of North

Carolina Press.

2000. "Dead Center? Rethinking the Middle for a Different Left." Social Text 65: 117-133.

2000. "Reading Capital for the Socializing Politics of Globalization." Society and Space 18: 37-51.

1999. "Globalization? The Dependencies of a Question." [Introduction to special issue of Social Text

on Globalization]. Edited with Gyan Prakash, 1-14. Social Text 60.

1999. "Stat(e)ing the Obvious." Edited by Randy Martin, 10-15. Workplace 4.

1999. "Courting Lesbianism." Co-authored with Jim McKay and Toby Miller. Women \&

Performance 11(1): 211-234.

1999. "Beyond Privatization? The Art and Society of Labor, Citizenship, and Consumerism." Social

Text 59: 35-48.

1999. "From the Studio to the Classroom: Critical Thinking and Pedagogical Performances." Review

of Education/Pedagogy/Cultural Studies 21(1): 1-14.

1999. "Leaping into the Dialectic: Etudes in Materializing the Social." In Politics/Poetics—Radical

Aesthetics for the Classroom. Edited by Amitava Kumar, 191-200. New York: St. Martin's Press. 1998/1999. "Rereading Marx: A Critique of Recent Criticisms." Science and Society 62(4): 513-536. 1999. "Introduction: Education as National Pedagogy." In Chalk Lines: The Politics of Work in the

Managed University. Edited by Randy Martin, 1-29. Durham, NC: Duke University Press.

1998. "What You Don't Get When You Cross Neo-Liberalism with Performativity: A Hint from

Havana." Conjunto 109. 
1998. "Fragmentation and Fetishism: The Postmodern in Marx." Critical Perspectives on Accounting 9(1): 77-98.

1998. "Staging Crisis: Twin Tales in Moving Politics." In The Ends of Performance. Edited by

Jill Lane and Peggy Phelan, 186-196. New York: New York University Press.

1997. “The Composite Body: Hip Hop Aerobics and the Multicultural Nation." Journal of Sport and

Social Issues 21(2): 120-133.

1997. “Academic Labor: An Introduction.” Edited by Randy Martin, 1-8. Social Text 51.

1996. "Cuba and the Rest." Social Text 48: 133-137.

1996. "Autonomy versus Ensemble as Socialist Principles." In Marxism Today: Essays on Capitalism,

Socialism and Strategies for Social Change. Edited by Chronis Polychroniou and Harry R. Targ, 143-156. Westport, CT: Praeger.

1995. "Resurfacing Socialism: Resisting the Appeals of Tribalism and Localism." Social Text 44: 97-118. 1995. "Over-Reading the 'Promised Land': Toward a Narrative of Context in Dance." In

Corporealities. Edited by Susan Leigh Foster, 177-198. London: Routledge.

1995. "Agency and History: The Demands of Dance Ethnography." In Choreographing History.

Edited by Susan Leigh Foster, 105-115. Bloomington, IN: Indiana University Press.

1995. "Left Futures." Co-authored with Michael E. Brown. Socialism and Democracy 9(1): 59-89.

1993. "Socialism and Democracy-Then and Now." Co-authored with Michael E. Brown and

Frank Rosengarten. Socialism and Democracy. 16/17: iii-ix.

1993. "Reasserting Dance in the Public Sphere: Toward a Critical View of Reconstruction." Dance

Reconstructed. Modern Dance Art Past, Present and Future.Conference Proceedings. Edited by

Barbara Palfy with Claudia Gitelman and Patricia Mayer, 119-126. New Brunswick, NJ:

Rutgers University.

1992. "Dance Ethnography and the Limits of Representation." Social Text 33: 103-123. [Reprinted

in Meaning in Motion. 1997. Edited by Jane Desmond, 321-344. Durham, NC: Duke University

Press].

1992. “Theater After the Revolution: Refiguring the Political in Cuba and Nicaragua." In On Edge:

Contemporary Culture in Latin America. Edited by Juan Flores, Jean Franco, and George Yúdice,

115-140. Minneapolis: University of Minnesota Press.

1992. "Introduction: Special Issue on Socialist Education." Socialism and Democracy 8(2-3): 3-9.

1991. "Rethinking the Crisis of Socialism." Co-Authored with Michael E. Brown. Socialism and

Democracy 7(3): 9-56.

1991. "Introduction: Socialism, Democracy and the New World Order." Co-Authored with Michael

E. Brown and Frank Rosengarten. Socialism and Democracy 12: iii-X.

1991. "Masquerades of Gender in a Nicaraguan Theater." Minnesota Review 36: 89-104.

1990. "Is The Body of Dance Sexed?" Journal of Dramatic Theory and Criticism 1: 7-24.

1990. "Cuban Theater Under Rectification." The Drama Review 34(1): 38-59. (Spanish translation

in CONJUNTO, Havana, Cuba.)

1989. "Expressive Motionality: Toward a Sociology of the Body." Journal of Learning about

Learning $1 / 3$.

1988. "Democratic Features of Socialism's Two Cultures." Socialism and Democracy 4(2): 121-137. 1987. "The Professional Army and Military Labor: The Battle for Internal Control." Sociological

Spectrum 7: 367-382.

1987. "Country and City in Nicaraguan Theater." The Drama Review 31(4): 58-76.

1987. "Nicaragua: State and Theater Without Walls." Social Text 18: 83-94.

1986. "Sowing the Threads of Resistance: Worker Resistance and Managerial Control in a Paint and

Garment Factory." Humanity and Society 10(3): 259-275.

1986. "Who Went to War." In The Vietnam Veteran Redefined: Fact and Fiction. Edited by

G. Boulanger and C. Kadushin, 13-24. Hillsdale: Erlbaum.

1985. "Dance as a Social Movement." Social Text 12: 54-70.

1985. "Library Resources." Socialism and Democracy 1(1): 33-44. 


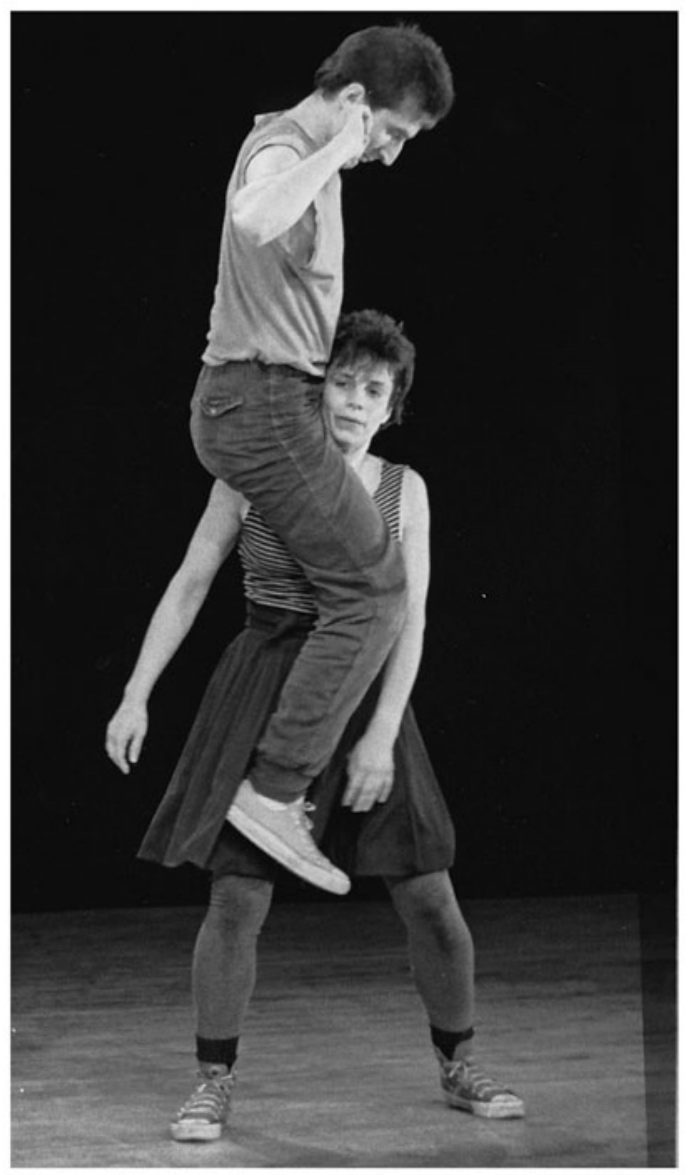

